\title{
Prevalence of sexually transmitted infections in HIV-1 infected pregnant women in Europe
}

\author{
Megan Landes · Claire Thorne · Patricia Barlow · Simona Fiore • \\ Ruslan Malyuta · Pasquale Martinelli - Svetlana Posokhova · Valeria Savasi • \\ Igor Semenenko · Andrej Stelmah · Cecilia Tibaldi · Marie-Louise Newell
}

Received: 20 March 2007 / Accepted: 18 September 2007 / Published online: 10 October 2007

(C) Springer Science+Business Media B.V. 2007

\begin{abstract}
We investigated prevalence of sexually transmitted infections (STI) in a cohort of HIV-1-infected pregnant women and described factors associated with STI diagnosis, as a nested study within the European Collaborative Study (ECS). The ECS is a cohort study in which HIV-infected pregnant women are enrolled and their children followed from birth, according to standard clinical and laboratory protocols. Information on STIs diagnosed during pregnancy was collected retrospectively from the antenatal records of women enrolling between January 1999 and October 2005; other variables were obtained from the ECS prospective database. A total of 1,050 women were included: 530 in Western Europe and 520 in Ukraine. Syphilis was the most common bacterial STI (2\% prevalence, 95\% CI 1.2-3.0). Prevalence of HPV-related genital lesions was $8.6 \%$ (95\%CI 6.9-10.4) and prevalence
\end{abstract}

Electronic Supplementary Material The online version of this article (doi:10.1007/s10654-007-9188-0) contains supplementary material, which is available to authorized users.

\section{Landes}

Department of Family and Community Medicine, University of Toronto, Toronto, Canada

C. Thorne $(\bowtie) \cdot$ S. Fiore · M.-L. Newell

Centre for Paediatric Epidemiology and Biostatistics, Institute of Child Health, University College London, 30 Guilford Street,

London WC1N 1EH, UK

e-mail: c.thorne@ich.ucl.ac.uk

\section{P. Barlow}

Department of Obstetrics and Gynecology, Hospital St Pierre, Brussels, Belgium

\section{S. Fiore · V. Savasi}

Department of Obstetrics and Gynecology, Hospital L.Sacco,

University of Milan, Milan, Italy of Trichomonas vaginalis was $12.1 \%$ (95\%CI 10.2-14.2). Women in Ukraine (AOR 10.7, 95\%CI 3.7-30.5), single women (AOR 3.9, 95\%CI 1.2-12.7), sexual partners of injecting drug users (AOR 3.8, 95\%CI 1.4-10.4) and women with $\mathrm{CD} 4$ counts $<200$ cells $/ \mathrm{mm}^{3}$ (AOR 5.4, 95\% CI 1.0-28.1) were at increased risk of diagnosis with Chlamydia trachomatis, syphilis or Trichomonas vaginalis. African origin (AOR 1.9, 95\%CI 1.1-3.3) and CD4 count $<200$ cells $/ \mathrm{mm}^{3}$ (AOR 3.4, 95\%CI 1.5-7.8) were associated with HSV-2 and/or HPV-related genital lesions. Antenatal screening should be considered an effective tool for diagnosis, treatment and prevention of further transmission of STIs. HIV-infected women should receive adequate screening for STIs during pregnancy together with appropriate counseling and follow-up for treatment and prevention.

R. Malyuta $\cdot$ I. Semenenko

Prevention of Perinatal AIDS Initiative, Odessa, Ukraine

P. Martinelli

Department of Gynecology and Obstetrics, University of Naples, Federico II, Naples, Italy

S. Posokhova

Department of Obstetrics and Gynecology, Odessa Regional Hospital, Odessa, Ukraine

A. Stelmah

AIDS Centre of Crimea, Simferopol, Ukraine

C. Tibaldi

Department of Obstetrics and Gynecology, Hospital S Anna, Turin, Italy 
Keywords Antenatal - Human immunodeficiency virus . Prevalence $\cdot$ Risk factors $\cdot$ Sexually transmitted infection

$\begin{array}{ll}\text { Abbreviations } \\ \text { CDC } & \text { Centers for Disease Control and Prevention } \\ \text { CI } & \text { Confidence interval } \\ \text { ECS } & \text { European Collaborative Study } \\ \text { HAART } & \text { Highly active antiretroviral therapy } \\ \text { HIV } & \text { Human immunodeficiency virus } \\ \text { HPV } & \text { Human papillomavirus } \\ \text { HSV-2 } & \text { Herpes simplex virus 2 } \\ \text { IDU } & \text { Injecting drug use } \\ \text { MTCT } & \text { Mother-to-child transmission } \\ \text { STI } & \text { Sexually transmitted infections }\end{array}$

\section{Introduction}

The number of women living with the human immunodeficiency virus (HIV) has dramatically risen in both Western and Eastern Europe during the last decade, reflecting both increased survival associated with highly active antiretroviral therapy (HAART) and increasing incidence, particularly in parts of Eastern Europe[1-4]. In the last decade, the character of the HIV epidemic among women in Europe has changed substantially. In Western Europe, heterosexual acquisition has now replaced injecting drug use (IDU) as the most common mode of acquisition among women, with a substantial majority of women infected heterosexually originating from countries with generalized epidemics $[1,5]$. In Eastern Europe, there has been a 20-fold increase in HIV prevalence in less than a decade [2] and a shift in the epidemic beyond initial core groups of IDUs, to bridging groups and into the general population, with the number of HIV infections reported as heterosexually acquired nearly doubling between 2001 and 2004 in Eastern Europe [1, 5, 6].

This increasing impact of sexual transmission in the propagation of HIV has spawned a considerable amount of research focusing on the relationship between sexually transmitted infections (STIs) and HIV. While both STIs and HIV share common acquisition risk factors such as high risk sexual behaviour, they also appear to have an "epidemiological synergy" [7, 8]. First, HIV seems to increase the risk of acquiring an STI [9] and secondly, STIs appear to increase the risk of both acquiring and transmitting HIV [10].

Most evidence for this epidemiological synergy is derived from research in the sexual transmission of HIV and the potential impact that STIs may have on maternal to child transmission (MTCT) of HIV has not been clearly quantified. An important first step in attempting to describe the role of STIs in MTCT of HIV is to estimate the prevalence of STIs amongst HIV-infected pregnant women, and to describe risk factors associated with their acquisition. To date, the prevalence and risk factors associated with STIs have been characterized amongst pregnant and non-pregnant women in the general population [11-15] and in non-pregnant HIV-infected women [16, 17], but not comprehensively amongst HIV-infected pregnant women. We took the opportunity to investigate the prevalence of STIs and associations between STI and socio-demographic characteristics of women as determined by current antenatal screening practices in a sub-set of the European Collaborative Study (ECS), a long-running MTCT cohort study [5, 18].

\section{Methods}

The ECS is a prospective cohort study in which HIVinfected pregnant women are enrolled and followed in pregnancy, and their children followed from birth, according to standard clinical and laboratory protocols [18]. The cohort began in 1985 and includes centres from Western and Central Europe and, most recently, Ukraine [5]. At each centre, women identified as HIV-infected during pregnancy, as well as those women identified as HIV-infected prior to pregnancy, were invited to participate. Before enrollment, informed consent was obtained according to local guidelines and ethics approval was granted in each centre. Maternal information routinely collected within the study protocol included socio-demographic characteristics, obstetrical history and HIV-specific information, but not STI infections.

Women from 15 ECS centres from seven countries were included in the nested STI study (Western Europe: Spain, Italy, the United Kingdom, Belgium, Sweden, Germany; and Ukraine). Information on STIs diagnosed during pregnancy was collected retrospectively from the antenatal records of women who delivered between January 1999 and October 2005 in all but the Ukrainian centres. This period was truncated to between January 2003 and May 2005 for the Ukrainian centres because of the large numbers of pregnant women enrolling in these centres, on average 200-250 women per year.

All centres followed the 1998 and, subsequently, the 2002 Centers for Disease Control guidelines for screening, diagnosis and treatment of STIs in pregnancy, except for one centre in Belgium with its own guidelines [19, 20]. All centres screened for STIs occurred during the first prenatal visit (12-28 weeks gestational age) and considered all women to be in the high risk category for STI screening on the basis of their HIV status, however screening practices differed slightly among centres.

There was no routine screening of $C$. trachomatis in one Western European centre, while all other centres routinely screened using endocervical sampling. C. trachomatis was rescreened for in the third trimester by all but two Western 
European centres. $N$. gonorrhea was not routinely screened for in two Western European centres, with one additional Western European centre not rescreening in the third trimester. All centres screened all women for syphilis using serological testing and all but two Western European centres rescreened for syphilis in the third trimester. All centres screened for cervical neoplasia only during the first trimester by Papanicolaou smear and all but two Western centres routinely screened all women by clinical exam in the first trimester for vulvar or vaginal lesions (indicating HSV-2 or genital warts). Women with abnormal cervical cytology or diagnosed cervical neoplasia were classified as having HPV-related genital lesions, as were women with genital warts. $T$. vaginalis was diagnosed on a case finding basis of symptomatic women as per screening guidelines.

Maternal variables included in the analysis were: age at delivery, region of birth, ethnicity, marital status and mode of HIV acquisition. Variables considered as proxies for sexual behaviour risk included: number of previous therapeutic pregnancy terminations, previous pregnancies and reporting a high risk sexual partner (e.g. IDUs). Laboratory variables included maternal CD4 cell counts and HIV RNA viral loads at enrollment; in the Ukraine centres, HIV RNA viral load quantification was not available, and CD4 cell count available for only a limited number of women due to lack of laboratory diagnostic capacity. Women with CD4 cell counts of $<200$ cells $/ \mathrm{mm}^{3}$ were classified as severely immunosuppressed.

Univariable analyses of factors associated with diagnosis with (1) C. trachomatis and/or syphilis and/or T. vaginalis and (2) HPV-related genital lesions and/or HSV-2 were carried out using the Pearson $\chi^{2}$ test. Crude odds ratios (ORs) were calculated and variables were selected for testing the fit of the multivariable model with a significance level of $P<0.10$ due to the small number of infections. Multivariable logistic regression was used to adjust for several factors simultaneously, to obtain adjusted odds ratios (AOR) and $95 \%$ confidence intervals (CI). Given the significant confounding of the variables region of birth, centre and ethnicity due to the homogeneity of the population from some of the centres, some variables were considered to be a priori risk factors (i.e. region of birth for viral STIs) based on other studies and given priority in the multivariable analysis [21]. All analyses were conducted using Intercooled STATA Version 9.0 (Stata Corporation, Texas, USA).

\section{Results}

\section{Study population}

Of the 1,050 women, $520(49.5 \%)$ were from centres in Ukraine and $530(50.5 \%)$ were enrolled in the Western
European centres. Socio-demographic characteristics are shown in Table 1. In Ukraine, $97 \%$ of women were white and born in Eastern Europe whereas over a third of women in the Western Europe centres were black Africans. Overall mean age at time of delivery was 28.3 years (95\% CI 27.928.7), with women living in Western Europe significantly older than those in Ukraine (31.3 vs. 25.9 years; $t=16.2$, $P=0.00)$. Women in Ukraine were more likely to be married compared to women in Western Europe (44\% vs. $31 \% ; P<0.001)$. Overall, $19 \%$ of women reported having a history of injecting drug use (IDU) (Table 1), with no significant geographic differences $(P=0.50)$ and only 27 women reported IDU during their pregnancy. Women in the Ukraine were much more likely to report being the sexual partner of an IDU than women in the West $(45.8 \%$ vs. $13.8 \% ; P=0.00)$.

Overall $45 \%(n=473)$ of women were aware of their HIV diagnosis when they became pregnant and the remainder were identified through antenatal testing ( $\mathrm{n}=531,51 \%)$ or through rapid testing at delivery ( $\mathrm{n}=29,3 \%$ ) (for 17 women the test date was not available). Median maternal CD4 cell count was 409 cells $/ \mathrm{mm}^{3}$ (range 7-1,790) and 10.2\% (59/579) of women were classified as severely immunosuppressed ( $<200$ cells/ $\mathrm{mm}^{3}$ ). Black women were more likely to be severely immunosuppressed than white women (17\% (29/174) vs. $8 \%$ (24/298), $P=0.002)$. Median RNA HIV viral load was 2,400 copies/ml $(n=371)$, with $52 \%$ of women having viral loads over 1,000 copies $/ \mathrm{ml}$.

\section{Prevalence of STIs}

Table 2 shows the prevalence of individual STIs in centres in Western Europe and the Ukraine, and for the total cohort. Overall, 257 women had an antenatal diagnosis with at least one bacterial or viral STI $(24.5 \%)$. Of these women, $18(1.7 \%)$ were diagnosed with two or more infections. Although for some infections there were similar prevalences in the Western European compared with the Ukrainian centres, there was a significantly higher prevalence of $T$. vaginalis $(P<0.001)$ and syphilis $(P=0.007)$ in Ukraine, with a higher prevalence of HPV-related genital lesions in Western Europe $(P<0.001)$.

Overall, $155(15 \%)$ women were diagnosed with at least one bacterial STI and $89 \%$ (140/158) of these infections were in women from the Ukraine. Regarding differential policies for re-screening for $C$. trachomatis, prevalence in sites with third trimester re-screening was $0.84 \%(6 / 714$; 95\% CI 0.3-1.8), not significantly different to that in the two sites with no re-screening $(1.45 \%, 4 / 275,95 \%$ CI $0.4-$ 3.9) (Fisher's exact test, $P=0.48$ ). Although prevalence of syphilis was higher in centres re-screening for syphilis than 
Table 1 Maternal and pregnancy characteristics, by geographic region

\begin{tabular}{|c|c|c|c|}
\hline & $\begin{array}{l}\text { Western Europe }(\mathrm{N}=530) \\
\mathrm{N}(\%)\end{array}$ & $\begin{array}{l}\text { Ukraine }(\mathrm{N}=520) \\
\mathrm{N}(\%)\end{array}$ & $\begin{array}{l}\text { Total }(\mathrm{N}=1,050) \\
\mathrm{N}(\%)\end{array}$ \\
\hline \multicolumn{4}{|l|}{ Region of birth } \\
\hline Western Europe & $222(43)$ & - & $222(21)$ \\
\hline Eastern Europe & $13(3)$ & $509(98)$ & $522(50)$ \\
\hline Africa & $187(35)$ & - & 189 (18) \\
\hline Other & $11(2)$ & 2 & $11(1)$ \\
\hline Unknown & 97 (18) & $9(2)$ & $106(10)$ \\
\hline \multicolumn{4}{|l|}{ Ethnicity } \\
\hline White & $240(45)$ & $505(97)$ & $745(71)$ \\
\hline Black & $188(36)$ & - & $188(18)$ \\
\hline Other & $8(2)$ & $13(3)$ & $21(2)$ \\
\hline Unknown & $94(18)$ & 2 & $96(9)$ \\
\hline \multicolumn{4}{|l|}{ Age (years) } \\
\hline $15-19$ & $9(2)$ & $29(6)$ & $38(4)$ \\
\hline $20-24$ & $45(9)$ & $206(40)$ & $251(24)$ \\
\hline $25-29$ & $105(20)$ & $165(32)$ & $270(26)$ \\
\hline $30-34$ & $130(25)$ & 89 (17) & $219(21)$ \\
\hline $35-39$ & $115(22)$ & $29(6)$ & 144 (14) \\
\hline$\geq 40$ & $26(5)$ & 1 & $27(3)$ \\
\hline Unknown & $87(17)$ & 1 & $88(9)$ \\
\hline \multicolumn{4}{|l|}{ Marital status } \\
\hline Single & $57(11)$ & $64(12)$ & $121(12)$ \\
\hline Married & $164(31)$ & $228(44)$ & 392 (37) \\
\hline Cohabiting & 107 (20) & $222(43)$ & $329(31)$ \\
\hline Divorced, separated, widowed & $36(7)$ & 2 & $38(4)$ \\
\hline Unknown & $166(31)$ & 4 & $170(16)$ \\
\hline \multicolumn{4}{|l|}{ Previous pregnancy } \\
\hline Yes $(\geq 1)$ & $403(76)$ & $304(42)$ & $707(67)$ \\
\hline No & $127(24)$ & $216(58)$ & $343(33)$ \\
\hline \multicolumn{4}{|l|}{ Previous pregnancy termination } \\
\hline 0 & $249(47)$ & $311(60)$ & $560(53)$ \\
\hline 1 & $133(25)$ & $102(20)$ & $235(22)$ \\
\hline 2 & $61(11)$ & $56(11)$ & $117(11)$ \\
\hline$\geq 3$ & $31(6)$ & $47(9)$ & $78(7)$ \\
\hline Unknown & $56(11)$ & $4(1)$ & $60(6)$ \\
\hline \multicolumn{4}{|l|}{ Sexual partner of IDU } \\
\hline Yes & $73(14)$ & $238(46)$ & $311(30)$ \\
\hline No & $426(80)$ & $272(52)$ & $698(67)$ \\
\hline Unknown & $31(6)$ & $10(2)$ & $41(4)$ \\
\hline \multicolumn{4}{|l|}{ History of IDU } \\
\hline Yes & $97(18)$ & $107(21)$ & $204(19)$ \\
\hline No & 409 (77) & $406(78)$ & $815(78)$ \\
\hline Unknown & $24(5)$ & $7(1)$ & $31(3)$ \\
\hline \multicolumn{4}{|l|}{ Timing of HIV Diagnosis } \\
\hline Pre-pregnancy & $339(64)$ & $134(26)$ & $473(45)$ \\
\hline Antenatal Screening & $173(33)$ & 358 (69) & $531(50)$ \\
\hline Delivery & 7 (1) & $22(4)$ & $29(3)$ \\
\hline Unknown & $11(2)$ & $6(1)$ & $17(2)$ \\
\hline
\end{tabular}


Table 1 continued

\begin{tabular}{|c|c|c|c|}
\hline & $\begin{array}{l}\text { Western Europe }(\mathrm{N}=530) \\
\mathrm{N}(\%)\end{array}$ & $\begin{array}{l}\text { Ukraine }(\mathrm{N}=520) \\
\mathrm{N}(\%)\end{array}$ & $\begin{array}{l}\text { Total }(\mathrm{N}=1,050) \\
\mathrm{N}(\%)\end{array}$ \\
\hline \multicolumn{4}{|c|}{ CD4 cell count $\left(\right.$ cells $\left./ \mathrm{mm}^{3}\right)$} \\
\hline$<200$ & $57(11)$ & 2 & $59(6)$ \\
\hline $200-499$ & $276(52)$ & $43(9)$ & $319(30)$ \\
\hline$\geq 500$ & $156(29)$ & $45(9)$ & $201(19)$ \\
\hline Unknown & $41(8)$ & $430(83)$ & $471(45)$ \\
\hline \multicolumn{4}{|c|}{ HIV RNA load (copies/ml) } \\
\hline$<50$ & $65(12)$ & - & $65(6)$ \\
\hline $50-1,000$ & $96(18)$ & - & $96(9)$ \\
\hline $1001-10,000$ & 98 (19) & - & $98(9)$ \\
\hline $10,001-100,000$ & $95(18)$ & - & $95(9)$ \\
\hline$>100,000$ & $17(3)$ & - & $17(2)$ \\
\hline Unknown & $159(30)$ & $520(100)$ & $679(65)$ \\
\hline \multicolumn{4}{|c|}{ Antenatal antiretroviral use } \\
\hline Yes & $424(80)$ & $415(80)$ & $839(80)$ \\
\hline No & $96(18)$ & $105(20)$ & $201(19)$ \\
\hline Unknown & $10(2)$ & - & $10(1)$ \\
\hline
\end{tabular}

Table 2 Prevalence of sexually transmitted infections, by geographic area and for the whole cohort

\begin{tabular}{|c|c|c|c|c|c|c|}
\hline & $\begin{array}{l}\text { Western Europe } \\
\mathrm{N}\end{array}$ & $\%(95 \% \mathrm{CI})$ & $\begin{array}{l}\text { Ukraine } \\
\mathrm{N}\end{array}$ & $\%(95 \% \mathrm{CI})$ & $\begin{array}{l}\text { Total } \\
\mathrm{N}^{\mathrm{a}}\end{array}$ & $\%(95 \% \mathrm{CI})$ \\
\hline \multicolumn{7}{|l|}{ Bacterial/protozoal STI } \\
\hline Chlamydia trachomatis $^{\mathrm{a}}$ & $5 / 445$ & $1.1(0.3-2.6)$ & $5 / 520$ & $1.0(0.3-2.2)$ & $10 / 965$ & $1.0(0.5-1.9)$ \\
\hline Neisseria gonorrhea ${ }^{\mathrm{a}}$ & $1 / 332$ & $0.3(0.003-0.6)$ & 0 & - & $1 / 852$ & $0.1(0.003-0.6)$ \\
\hline Syphilis $^{\mathrm{a}}$ & $4 / 530$ & $0.8(0.2-1.9)$ & $17 / 520$ & $3.3(1.9-5.2)$ & $21 / 1,050$ & $2.0(1.2-3.0)$ \\
\hline Trichomonas vaginalis ${ }^{\mathrm{b}}$ & $9 / 530$ & $1.7(0.8-3.2)$ & $118 / 520$ & $22.7(19.2-26.5)$ & $127 / 1,050$ & $12.1(10.2-14.2)$ \\
\hline \multicolumn{7}{|l|}{ Viral STI } \\
\hline Herpes simplex virus $2^{a}$ & $4 / 256$ & $1.6(0.8-2.7)$ & $8 / 520$ & $1.5(0.7-3.0)$ & $12 / 776$ & $1.5(0.8-2.7)$ \\
\hline Herpes simplex virus $2^{\mathrm{b}}$ & $15 / 161$ & $9.3(5.3-14.9)$ & & & & \\
\hline HPV-related genital lesions ${ }^{a}$ & $81 / 530$ & $15.3(12.3-18.6)$ & $9 / 520$ & $1.7(0.8-3.3)$ & $90 / 1,050$ & $8.6(6.9-10.4)$ \\
\hline
\end{tabular}

${ }^{a}$ cases over total screened, limited to centres with universal screening

b case-finding among symptomatic women

in those with a single screening, this did not achieve statistical significance $(2.3 \%$ [19/841, 95\% CI 1.4-3.5] vs. $1.0 \% \quad[2 / 209,95 \%$ CI 0.1-3.4]; Fisher's exact test $P=0.40)$. In total, 108 women $(10 \%)$ were diagnosed with at least one viral STI.

Factors associated with STI diagnosis

Timing of HIV diagnosis was not univariably associated with risk of being diagnosed with an STI in pregnancy $\left(\chi^{2}=0.32, P=0.57\right)$; overall, the prevalence of an STI was $23.4 \%$ for women diagnosed pre-pregnancy and $25.2 \%$ for those diagnosed during pregnancy/at delivery.
Factors univariably associated with antenatal diagnosis with syphilis, $C$. trachomatis or $T$. vaginalis among women from centres with universal screening for these infections included birth and/or residence in Ukraine, single or cohabiting marital status, current IDU and reported previous or current partner who used injecting drugs and HIV diagnosis during pregnancy (increased risk) and black race and age above 30 years (decreased risk) (Table 3 ). In the subgroup of women with CD4 cell counts available, the same risk factors were identified univariably, but race, marital status and current IDU were no longer associated with a statistically significant increased risk.

In multivariable logistic regression analysis of 337 women with CD4 cell counts available, women from 


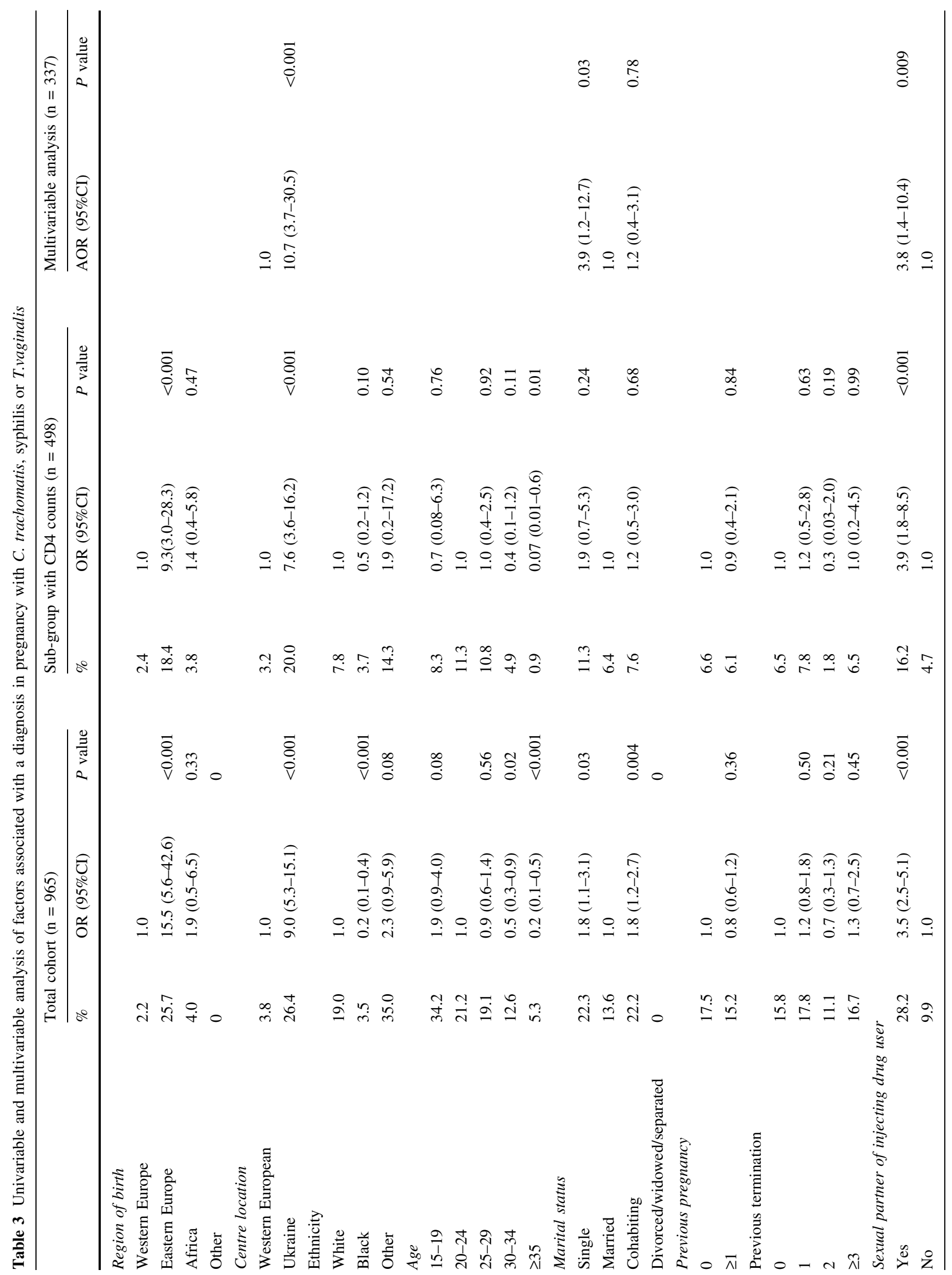




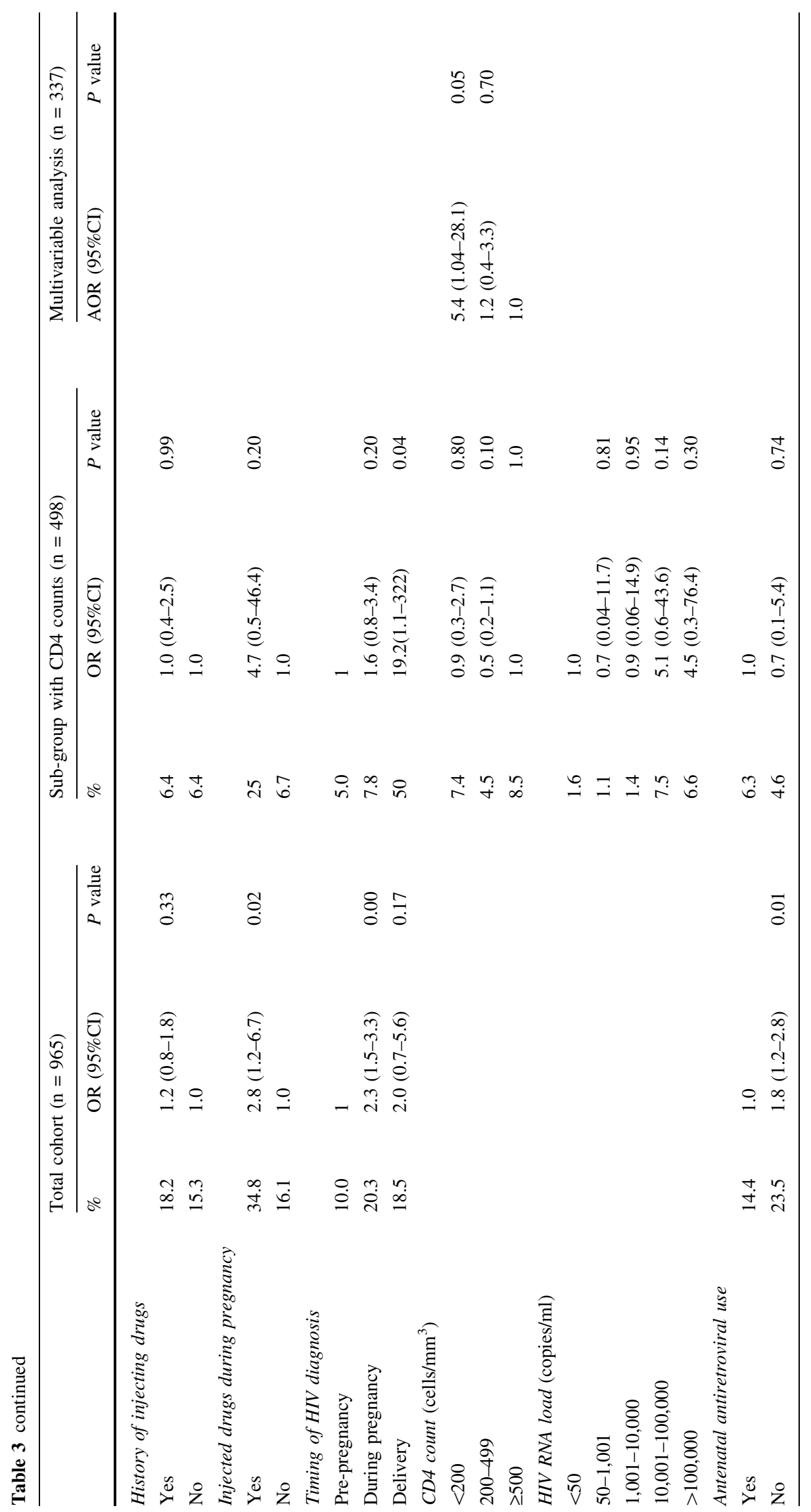


Ukraine were almost 11 times more likely than other women to have an antenatal diagnosis of syphilis, C. trachomatis or $T$. vaginalis, single women had almost a fourfold increased risk compared with married women and women with IDU sexual partners had a near four-fold increased risk (Table 3). Women with severe immunosuppression were nearly five and a half times more likely to have a bacterial STI diagnosed than women with CD4 cell counts $>500$ cells $/ \mathrm{mm}^{3}$.

Univariable analyses identified several factors associated with an increased likelihood of diagnosis with HSV-2 and/or HPV-related genital lesions in pregnancy, including being born in Africa, maternal age over 30 years, separated, divorced or widowed marital status and severe immunosuppression (Table 4). Being born in Ukraine and/ or residence in the Ukraine, having an IDU sexual partner and HIV diagnosis at antenatal screening visit were associated with a decreased risk of HSV-2 and/or HPV-related genital lesions. Similar risks were identified within the subgroup of women with CD4 cell counts, except being the sexual partner of an IDU lost statistical significance and timing of HIV diagnosis was only of borderline significance; in this subgroup, women who were severely immunosuppressed were almost five times more likely to be diagnosed with HSV-2 and/or HPV than those with CD4 cell counts above 499 cells $/ \mathrm{mm}^{3}$. Only women born in Africa and women who were severely immunosuppressed remained at a statistically significant increased risk of these viral STI in multivariable analysis, with the former having nearly a doubled risk compared with Western European women and the latter a three-fold increased risk vs. immunocompetent women (Table 4). Women born in Ukraine remained much less likely to be diagnosed with HSV-2 and/or HPV than those born in Western Europe.

\section{Discussion}

In this European study, 25\% of HIV-infected women were diagnosed with one or more STIs during their pregnancy, with $15 \%$ diagnosed with at least one bacterial STI and $10 \%$ with HSV-2 infection or HPV-related genital lesions. Marked geographic differences in the prevalence of STIs existed with women in Ukraine having much higher prevalence rates of syphilis and $T$. vaginalis than women in Western Europe, of whom just over a third were black African women. The higher prevalence of syphilis in Ukraine reflects regional estimates reported by the World Health Organization where the population incidence of syphilis in the Ukraine was nearly 50-100 times that reported in the most Western European countries [22]. Likewise, our estimate of $T$. vaginalis as the most commonly diagnosed STI in pregnancy in Ukraine is consistent with WHO surveillance data [12]. The dramatic rise in incidence of STIs in Ukraine and other regions in the former USSR associated with economic transition indicates an increase in prevalence of risky sexual behaviours [23] and is likely to have been instrumental in the rapid evolution of the HIV epidemic in Ukraine, where there is now an estimated HIV prevalence of 1-1.5\% [2].

Viral STIs demonstrated the inverse geographical relationship to bacterial STIs, with prevalence in Western Europe substantially higher than in Ukraine. Of note, the prevalence of HSV-2 in Western Europe was double that in Ukraine, with over $60 \%$ of diagnosed HSV-2 infections in Western Europe occurring in African women. This regional difference likely reflects the more heterogeneous population of the Western European centres, with significant migration from African countries with higher prevalences of viral STIs. Given the natural history of viral STIs, that is their persistence and tendency for episodic reactivation [24], and the timing of antenatal screening tests, it is likely that many viral infections diagnosed during pregnancy represent infections acquired before pregnancy, thus placing women from highly endemic regions of Africa at increased risk where, for example, prevalence levels for HSV-2 in some countries reach 80\% [25-27].

The literature suggests that a higher prevalence of bacterial and viral STIs can be expected in HIV-infected cohorts than in non-HIV infected cohorts even after controlling for sexual behaviour [9, 28, 28, 29]. While our overall STI prevalence estimates are consistent with those from another recent study of HIV-infected non-pregnant women in Europe, the prevalences of chlamydia and gonorrhea were notably lower [16]. However, a recent study by Chen et al. of HIV-infected pregnant women in New York found similarly low chlamydia and gonorrhea prevalence [30].

Relatively little is known about sexual behaviour in pregnancy in the general population, and even less in the HIV-infected pregnant population. This study has similar limitations, lacking sufficient sexual behaviour data amongst our cohort. However, pregnancy indicates that unprotected sex has occurred and several studies in the general population have suggested that pregnancy is not a time of decreased sexual risk-taking [31, 32]. In a recent European survey of reproductive choices and sexual practices among HIV-infected women, including 121 pregnant women, $12 \%$ abstained from sex during pregnancy and of those sexually active, $58 \%$ were not using barrier contraception [33].

Our finding that single women and those with a history of having sex with an IDU were significantly more likely to be diagnosed with a bacterial STI infection is consistent with the literature, where both variables have been used as proxies for high risk sexual behaviour in the general population and amongst HIV-infected individuals [11, 34]. 
Table 4 Univariable and multivariable analysis of risk factors for HSV-2 and/or HPV-associated genital lesions

\begin{tabular}{|c|c|c|c|c|c|c|c|c|}
\hline & \multicolumn{3}{|c|}{ Total cohort $(n=1,050)$} & \multicolumn{3}{|c|}{ Sub-group with CD4 counts $(n=579)$} & \multicolumn{2}{|c|}{ Multivariable analysis } \\
\hline & $\%$ & OR $(95 \% \mathrm{CI})$ & $P$ value & $\%$ & OR $(95 \% \mathrm{CI})$ & $P$ value & AOR $(95 \% \mathrm{CI})$ & $P$ value \\
\hline \multicolumn{9}{|l|}{ Region of birth } \\
\hline Western Europe & 14.9 & 1.0 & & 15.5 & 1.0 & & 1.0 & \\
\hline Eastern Europe & 3.3 & $0.2(0.1-0.4)$ & $<0.001$ & 2.9 & $0.2(0.05-0.5)$ & $<0.003$ & $0.17(0.05-0.6)$ & 0.007 \\
\hline Africa & 25.4 & $1.9(1.2-3.2)$ & 0.01 & 27.3 & $2.0(1.2-3.4)$ & 0.005 & $2.0(1.2-3.6)$ & 0.01 \\
\hline Other & 9.1 & $0.6(0.1-4.6)$ & 0.60 & 9.1 & $0.5(0.06-4.4)$ & 0.57 & $0.8(0.09-6.7)$ & 0.83 \\
\hline \multicolumn{9}{|l|}{ Centre location } \\
\hline Western Europe & 17.2 & 1.0 & & 17.8 & 1.0 & & & \\
\hline Ukraine & 3.3 & $0.2(0.1-0.3)$ & $<0.001$ & 3.3 & $0.2(0.05-0.5)$ & 0.002 & & \\
\hline \multicolumn{9}{|l|}{ Ethnicity } \\
\hline White & 6.7 & 1.0 & & 11.2 & 1.0 & & & \\
\hline Black & 25.0 & $4.6(2.0-7.2)$ & $<0.001$ & 26.4 & $2.9(1.8-4.6)$ & $<0.001$ & & \\
\hline Other & 9.5 & $1.5(0.3-6.5)$ & 0.62 & 25.0 & $2.6(0.5-13.6)$ & 0.24 & & \\
\hline Age & & & & & & & $\begin{array}{l}\text { Adjusted for } \\
\text { age with a } \\
\text { continuous va } \\
\text { Age } 0.94(0.9-1\end{array}$ & able 0.01 \\
\hline 15-19 & 7.9 & $1.0(0.3-3.7)$ & 0.9 & 25.0 & $2.5(0.6-11.1)$ & 0.22 & & \\
\hline $20-24$ & 7.6 & 1.0 & & 11.7 & 1.0 & & & \\
\hline $25-29$ & 9.3 & $1.2(0.7-2.3)$ & 0.5 & 18.1 & $1.7(0.7-3.8)$ & 0.22 & & \\
\hline $30-34$ & 16.4 & $2.4(1.3-4.3)$ & 0.004 & 24.4 & $2.4(1.1-5.4)$ & 0.03 & & \\
\hline$\geq 35$ & 9.4 & $1.3(0.6-2.5)$ & 0.51 & 10.2 & $0.9(0.4-2.1)$ & 0.73 & & \\
\hline \multicolumn{9}{|l|}{ Marital status } \\
\hline Single & 10.7 & $1.4(0.7-2.8)$ & 0.33 & 18.3 & $1.5(0.7-3.1)$ & 0.34 & & \\
\hline Married & 7.9 & 1.0 & & 13.4 & 1.0 & & & \\
\hline Cohabiting & 10.6 & $1.4(0.8-2.3)$ & 0.21 & 19.1 & $1.5(0.9-2.8)$ & 0.16 & & \\
\hline Divorced/widowed/separated & 28.9 & $4.7(2.2-10.5)$ & $<0.001$ & 28.1 & $2.5(1.1-6.1)$ & 0.04 & & \\
\hline \multicolumn{9}{|l|}{ Previous pregnancy } \\
\hline 0 & 9.6 & 1.0 & & 15.0 & 1.0 & & & \\
\hline$\geq 1$ & 10.6 & $1.1(0.7-1.7)$ & 0.62 & 15.7 & $1.1(0.6-1.8)$ & 0.84 & & \\
\hline \multicolumn{9}{|l|}{ Previous termination } \\
\hline 0 & 9.8 & 1.0 & & 15.5 & 1.0 & & & \\
\hline 1 & 14.0 & $1.5(0.9-2.4)$ & 0.09 & 20.8 & $1.4(0.9-2.4)$ & 0.17 & & \\
\hline 2 & 7.7 & $0.8(0.4-1.6)$ & 0.48 & 10.9 & $0.7(0.3-1.6)$ & 0.31 & & \\
\hline$\geq 3$ & 6.4 & $0.6(0.2-1.6)$ & 0.34 & 9.5 & $0.6(0.2-1.7)$ & 0.31 & & \\
\hline \multicolumn{9}{|c|}{ Sexual partner of injecting drug user } \\
\hline Yes & 5.8 & $0.4(0.3-0.7)$ & 0.002 & 16.7 & $0.7(0.3-1.3)$ & 0.23 & & \\
\hline No & 12.3 & 1.0 & & 11.7 & 1.0 & & & \\
\hline \multicolumn{9}{|l|}{ History of injecting drugs } \\
\hline Yes & 9.3 & $0.9(0.5-1.5)$ & 0.60 & 13.6 & $0.8(0.5-1.5)$ & 0.50 & & \\
\hline No & 10.6 & 1.0 & & 16.2 & 1.0 & & & \\
\hline \multicolumn{9}{|c|}{ Injected drugs during pregnancy } \\
\hline Yes & 7.4 & $0.7(0.2-3.0)$ & 0.62 & 28.6 & $1.9(0.4-10.2)$ & 0.44 & & \\
\hline No & 10.4 & 1.0 & & 17.1 & 1.0 & & & \\
\hline \multicolumn{9}{|l|}{ Timing of diagnosis } \\
\hline Pre-pregnancy & 14.8 & 1.0 & & 17.8 & 1.0 & & & \\
\hline Antenatal Screening & 6.8 & $0.4(0.3-0.6)$ & 0.00 & 12.0 & $0.6(0.4-1.0)$ & 0.06 & $0.5(0.3-0.9)$ & 0.03 \\
\hline Delivery & 3.5 & $0.2(0.03-1.5)$ & 0.12 & 33.3 & $2.3(0.2-25.9)$ & 0.5 & $3.2(0.2-57.7)$ & 0.43 \\
\hline
\end{tabular}


Table 4 continued

\begin{tabular}{|c|c|c|c|c|c|c|c|c|}
\hline & \multicolumn{3}{|c|}{ Total cohort $(\mathrm{n}=1,050)$} & \multicolumn{3}{|c|}{ Sub-group with CD4 counts $(n=579)$} & \multicolumn{2}{|c|}{ Multivariable analysis } \\
\hline & $\%$ & OR $(95 \% \mathrm{CI})$ & $P$ value & $\%$ & OR $(95 \% \mathrm{CI})$ & $P$ value & AOR $(95 \% \mathrm{CI})$ & $P$ value \\
\hline \multicolumn{9}{|c|}{ CD4 count $\left(\right.$ cells $\left./ \mathrm{mm}^{3}\right)$} \\
\hline$<200$ & & & & 40.0 & $5.8(2.9-11.6)$ & $<0.001$ & $5.2(2.4-11.1)$ & $<0.001$ \\
\hline $200-499$ & & & & 14.7 & $1.6(0.9-2.7)$ & 0.12 & $1.3(0.7-2.4)$ & 0.39 \\
\hline$\geq 500$ & & & & 10.0 & 1.0 & & 1.0 & \\
\hline \multicolumn{9}{|c|}{ HIV RNA load (copies/ml) } \\
\hline$<50$ & & & & 30.8 & 1.0 & & & \\
\hline $50-1,001$ & & & & 11.5 & $0.3(0.1-0.7)$ & 0.003 & & \\
\hline $1,001-10,000$ & & & & 8.2 & $0.2(0.08-0.5)$ & $<0.001$ & & \\
\hline $10,001-100,000$ & & & & 27.4 & $0.8(0.4-1.7)$ & 0.64 & & \\
\hline$>100,000$ & & & & 17.7 & $0.5(0.1-1.9)$ & 0.29 & & \\
\hline unknown & & & & 10.6 & $0.3(0.1-0.5)$ & $<0.001$ & & \\
\hline \multicolumn{9}{|c|}{ Antenatal antiretroviral use } \\
\hline Yes & 11.2 & 1.0 & & 16.5 & 1.0 & & & \\
\hline No & 5.5 & $0.5(0.2-0.9)$ & 0.02 & 9.3 & $0.5(0.2-1.1)$ & 0.10 & & \\
\hline
\end{tabular}

Consistent condom use by male IDUs is reportedly low and condom use is often less common with their primary sexual partners than with casual sexual partners [35], thus women with IDU sex partners are at risk from their partners' risk behaviors with both sexual and injecting partners.

In our study, women with severe immunosuppression were substantially more likely to be diagnosed with a STI, independent of other factors. McClelland et al. found similarly increased risks and hypothesized that HIV disease progression may influence susceptibility to bacterial STIs, duration of infection and/or response to treatment [9]. This and other studies have shown an increased prevalence of viral STIs with increasing immunodeficiency [9, 36, 37]. Frequent sub-clinical and clinical reactivations of viral infections and prolonged duration of infection with progressive immunodeficiency have been documented in HIV-infected persons co-infected with viral STIs [38]. Recent studies have indicated the important interactions between HIV RNA levels and CD4 counts with prevalent and incident detection of viral STIs, in particular HPV [39]. However, few studies have the statistical power to include a stratified analysis of combined HIV RNA levels and CD4 counts, including ours.

With regard to HPV infection prevalence, we will have underestimated the true prevalence in this population, as we report on the prevalence of clinical manifestations of HPV infection as identified with a Pap smear or clinical exam rather than a definitive diagnosis of HPV infection. The presence of genital lesions/abnormal cervical cytology has high sensitivity for underlying HPV infection, but low specificity, as HPV infection will not necessarily lead to cytological abnormalities. Furthermore, there are issues regarding the interpretation of Pap smears in the first trimester, due to normal physiological changes at that time. Although HPV prevalence is known to be higher in younger women, abnormal cervical cytology or diagnosed cervical neoplasia are more common in older women, which explains our finding of an increased risk of HPVassociated lesions in women aged 30-34 years [40].

Our study has several limitations: first, as this nested study is within a multi-centre observational study, prevalence data may be affected by differential screening practices. However, for infections such as syphilis which was universally screened for, we can be confident in our prevalence estimates. Whilst most studies have shown association between the risk of STIs and high risk sexual behaviour, the data available on sexual behaviour in the ECS consists mostly of distal indicators or proxy measures. Finally, as the information collected on STI diagnosis was cross-sectional (i.e. limited to pregnancy), we had no information on the timing of acquisition of STIs, only that they were diagnosed in pregnancy.

Our findings demonstrate a substantial prevalence of coinfection with STIs in pregnant HIV-infected women in Europe. Antenatal screening should be considered an effective tool for the diagnosis, treatment and prevention of further transmission of STIs. The identification and treatment of STIs in this population will not only benefit the individual woman and her sexual partners, but also her infant with the protection from adverse outcomes including congenital infection. It is therefore imperative that HIVinfected women receive adequate screening for STIs during the antenatal period and appropriate counseling and followup for treatment and prevention. 
Acknowledgements Sources of support: The European Collaborative Study is a coordination action of the European Commission (Framework 6) (PENTA/ECS 018865). The Medical Research Council (UK) Sexual Health and HIV Research Strategy Committee provided support to the ECS coordinating centre. The views expressed are those of the authors and not necessarily those of the MRC or the Health Departments.ECS collaborators: We thank Deven Patel and Kirsty England at the ECS coordinating centre. The ECS collaborators at the participating centres were Professor J. Levy, Dr M. Hainaut, Dr T.Goetghebuer, Dr P. Barlow, Dr Y. Manigart (Brussels); Dr V. Savasi, Dr S. Fiore, Prof E. Ferrazzi, Dr A. Viganò, Dr V. Giacomet, Dr M. Crivelli (Milan); Prof P. Martinelli, Dr A. Agangi, Drssa W. Buffolano, Dr R. Tiseo, Drssa M. Sansone (Naples); Dr C. Tibaldi, Dr S. Marini, Dr G. Masuelli, Prof C. Benedetto (Turin); Prof I. Grosch-Wörner, Dr C. Feiterna-Sperling, Dr S. Casteleyn (Berlin); Dr A.B. Bohlin, Dr S. Lindgren, Dr K. Elfgren, Dr B. Anzén and Dr K. Lidman (Huddinge and Solna); Prof A. Mûr, Dr A. Payà, Dr M.A. López-Vilchez, Dr R. Carreras (Barcelona); Dr J. Jimenez (Madrid); Dr O. Coll, Dr S. Hernández, Dr J. Pascual (Barcelona); Dr S. Alberico, Dr M. Rabusin, M. Bernardon (Trieste). Dr R. Malyuta, Dr I. Semenenko, Dr. I. Shevchenko, T. Pilipenko, Dr. D. Richko, Y. Khomout (Perinatal Prevention of AIDS Initiative, Odessa), Dr S. Posokhova, Dr T. Kaleeva, Dr. A. Shelyag, Dr. S. Servetsky (Odessa), Dr A. Stelmah, Dr. G. Kiseleva, Dr O.A. Zalata (Crimean Republic).

\section{References}

1. EuroHIV (European Centre for the Epidemiological Monitoring of AIDS). HIV/AIDS surveillance in Europe, mid-year report 2005. 72. 2006. Paris: EuroHIV.

2. UNAIDS (2006) Report on the global AIDS epidemic, 2006. Geneva: UNAIDS.

3. D'Arminio MA, Sabin CA, Phillips A, et al. The changing incidence of AIDS events in patients receiving highly active antiretroviral therapy. Arch Intern Med 2005;165:416-23.

4. Sterne JA, Hernan MA, Ledergerber B, et al. Long-term effectiveness of potent antiretroviral therapy in preventing AIDS and death: a prospective cohort study. Lancet 2005;366:378-84.

5. European Collaborative Study: The mother-to-child HIV transmission epidemic in Europe: evolving in the East and established in the West. AIDS 2006;20:1419-27.

6. UNAIDS. The changing HIV/AIDS epidemic in Europe and Central Asia. 2004. Geneva, UNAIDS. http://data.unaids.org/ Publications/IRC-pub06/jc1038-changingepidemic_en.pdf. Accessed 1 Mar 2007.

7. Wasserheit JN. Epidemiological synergy. Interrelationships between human immunodeficiency virus infection and other sexually transmitted diseases. Sex Transm Dis 1992;19:61-77.

8. Cohen MS. HIV and sexually transmitted diseases: lethal synergy. Top HIV Med 2004;12:104-7.

9. McClelland RS, Lavreys L, Katingima C, et al. Contribution of HIV-1 infection to acquisition of sexually transmitted disease: a 10-year prospective study. J Infect Dis 2005;191:333-8.

10. Rottingen JA, Cameron DW, Garnett GP. A systematic review of the epidemiologic interactions between classic sexually transmitted diseases and HIV: how much really is known? Sex Transm Dis 2001;28:579-97.

11. Radcliffe KW, Ahmad S, Gilleran G, Ross JD. Demographic and behavioural profile of adults infected with chlamydia: a casecontrol study. Sex Transm Infect 2001;77:265-70.

12. Mavrov GI, Bondarenko GM. The evolution of sexually transmitted infections in the Ukraine. Sex Transm Infect 2002;78: 219-21.
13. Brown AE, Sadler KE, Tomkins SE, et al. Recent trends in HIV and other STIs in the United Kingdom: data to the end of 2002. Sex Transm Infect 2004;80:159-66.

14. Leszczynska-Gorzelak B, rmochwal-Kolarz D, BorowiecBlinowska A, Oleszczuk J: The prevalence of Chlamydia trachomatis infection in pregnant women. Med Wieku Rozwoj 2005;9:27-35.

15. Ickovics JR, Niccolai LM, Lewis JB, Kershaw TS, Ethier KA: High postpartum rates of sexually transmitted infections among teens: pregnancy as a window of opportunity for prevention. Sex Transm Infect 2003;79:469-73.

16. van Benthem BH, Prins M, Larsen C, Delmas MC, Brunet JB, van den HA. Sexually transmitted infections in European HIVinfected women: incidence in relation to time from infection. European Study on the Natural History of HIV Infection in Women. AIDS 2000;14:595-603.

17. Magnus M, Clark R, Myers L, Farley T, Kissinger PJ. Trichomonas vaginalis among HIV-Infected women: are immune status or protease inhibitor use associated with subsequent $T$. vaginalis positivity? Sex Transm Dis 2003;30:839-43.

18. European Collaborative Study. Mother-to-child transmission of HIV infection in the era of highly active antiretroviral therapy. Clin Infect Dis 2005;40:458-65.

19. Centers For Disease Control and Prevention. 1998 Guidelines for treatment of sexually transmitted diseases. MMWR 1998;47: $1-116$.

20. Centers For Disease Control and Prevention. Guidelines for the treatment of sexually transmitted diseases - 2002. MMWR 2002;51:1-78.

21. Mbopi-Keou FX, Gresenguet G, Mayaud P, et al. Interactions between herpes simplex virus type 2 and human immunodeficiency virus type 1 infection in African women: opportunities for intervention. J Infect Dis 2000;182:1090-6.

22. World Health Organisation Regional Office for Europe. Centralized Information Service for Infectious Disease. 2006. http://data.euro. who.int/cisid/?TabID $=48830$. Accessed 1 Mar 2007.

23. Rhodes T, Simic M. Transition and the HIV risk environment. BMJ 2005;331:220-3.

24. Celum C, Levine R, Weaver M, Wald A. Genital herpes and human immunodeficiency virus: double trouble. Bull World Health Organ 2004;82:447-53.

25. Greenblatt RM, Lukehart SA, Plummer FA et al. Genital ulceration as a risk factor for human immunodeficiency virus infection. AIDS 1988;2:47-50.

26. Weiss HA, Buve A, Robinson NJ et al. The epidemiology of HSV-2 infection and its association with HIV infection in four urban African populations. AIDS 2001;15 Suppl 4:S97-108.

27. Freeman EE, Glynn JR. Factors affecting HIV concordancy in married couples in four African cities. AIDS 2004;18:1715-21.

28. Greenblatt RM, Bacchetti P, Barkan S, et al. Lower genital tract infections among HIV-infected and high-risk uninfected women: findings of the Women's Interagency HIV Study (WIHS). Sex Transm Dis 1999;26:143-51.

29. Palefsky JM, Minkoff H, Kalish LA et al. Cervicovaginal human papillomavirus infection in human immunodeficiency virus-1 (HIV)-positive and high-risk HIV-negative women. J Natl Cancer Inst 1999;91:226-36.

30. Chen KT, Segu M, Lumey LH, et al. Genital herpes simplex virus infection and perinatal transmission of human immunodeficiency virus. Obstet Gynecol 2005;106:1341-8.

31. Wilson TE, Minkoff H, McCalla S, Petterkin C, Jaccard J: The relationship between pregnancy and sexual risk taking. Am J Obstet Gynecol 1996;174:1033-6.

32. Niccolai LM, Ethier KA, Kershaw TS, Lewis JB, Ickovics JR. Pregnant adolescents at risk: sexual behaviors and sexually 
transmitted disease prevalence. Am J Obstet Gynecol 2003; 188:63-70.

33. Fiore S. HIV infected women in Europe. PhD thesis. University of London; 2005.

34. Sorvillo F, Kovacs A, Kerndt P, Stek A, Muderspach L, SanchezKeeland L. Risk factors for trichomoniasis among women with human immunodeficiency virus (HIV) infection at a public clinic in Los Angeles County, California: implications for HIV prevention. Am J Trop Med Hyg 1998;58:495-500.

35. Rosengard C, Anderson B, Stein MD. Intravenous drug users' HIV-risk behaviors with primary/other partners. Am J Drug Alcohol Abuse 2004;30:225-36.

36. Silverberg MJ, Ahdieh L, Munoz A, et al. The impact of HIV infection and immunodeficiency on human papillomavirus type 6 or 11 infection and on genital warts. Sex Transm Dis 2002;29:427-35.
37. Fennema JS, van Ameijden EJ, Coutinho RA, van den Hoek AA. HIV, sexually transmitted diseases and gynaecologic disorders in women: increased risk for genital herpes and warts among HIV-infected prostitutes in Amsterdam. AIDS 1995;9:1071-8.

38. Corey L, Wald A, Celum CL, Quinn TC. The effects of herpes simplex virus- 2 on HIV-1 acquisition and transmission: a review of two overlapping epidemics. J Acquir Immune Defic Syndr 2004;35:435-45.

39. Strickler HD, Burk RD, Fazzari M et al. Natural history and possible reactivation of human papillomavirus in human immunodeficiency virus-positive women. J Natl Cancer Inst 2005; 97:577-86.

40. Dunn EF, Markowitz LE. Genital human papillomavirus infection. Clin Inf Dis 2006;43: 624-9. 